Rev. Andrzej Proniewski

University of Biatystok

\title{
Ratzinger's Reflections on the Staurological Foundation of the Resurrection
}

Jesus' Cross, death, and Resurrection are events from His life that paved the way for man's salvation. The Son of God's passion and death on the Cross led to the Resurrection. Because of Jesus Christ's Resurrection, every person who remains in union with him can count on experiencing his own personal resurrection. Christ took up the Cross out of love for man and, in so doing, paved the way to eternal life. The prospect of eternal life was made possible for man through Jesus' redemption, which He achieved on the cross and brought to completion in the Resurrection. Because of this greatest of mysteries, man's union with God does not cease when he dies, but rather continues within God's eternal life. This article considers Ratzinger's theology that presents the staurological basis of the mystery of the Resurrection and is organized into three categories: the Cross, death, and the Resurrection. When man lives with Christ, he enters into a relationship of love that leads to the cross, which transforms time and is a precursor to eternity.

Key words: Jesus Christ, cross, death, Resurrection, eternity.

The prospect of eternal life was made possible for man through Jesus' redemption, which $\mathrm{He}$ achieved on the cross and brought to completion in the Resurrection. Because of this greatest of mysteries, man's union with God does not cease when he dies, but rather continues within God's eternal life. Why did the Savior die on a cross? What enduring message does the mystery of the Savior's death convey? What was the purpose of Christ's death on the cross? The answers to these questions have been organized in this article according to the following three points: the cross, death, and the resurrection. 


\section{The Cross}

The Cross of Jesus Christ is a manifestation of Divine Mercy to man. St. Paul conveys the inner connection between Christ's cross and His Resurrection. Based on the tradition that was handed on to him, St. Paul presented a deeper New Testament theology of the cross and made the cross the central focus of his preaching (1 Cor 1:23).

Fundamental Theology

St. Paul explains that not just a man, but the Son of God Himself, who had a desire to identify deeply with sinful humanity, hung on the cross (1 Cor 1:30) in order to redeem man before God. The way through the cross became the seal of the revelation of the unfathomable mystery of redemption and the infinite depths of God's Love. ${ }^{1}$

Joseph Ratzinger explains that Jesus became not only the Lord of man but also the hope for all humanity because of the circumstances of the cross and the Son of God's victory over death. The theology of the Cross brought about a dynamic, timely, and critical recognition of the Christian life, the fulfillment of which was made possible only in the Resurrected Christ. The God-Man's mediation on the Cross restored the harmony and order of man's relationship with God that he disrupted at the beginning of creation. By dying on the cross, Jesus Christ inaugurated the process of eternal atonement for which man was unable to give himself because he is sinful and finite. Christ's death on the cross turned the tide of events and effectively redeemed sinful humanity. ${ }^{2}$

Joseph Ratzinger describes in detail the specific events pertaining to the cross and states that the first words that Jesus spoke during his crucifixion were: "Father, forgive them, they know not what they do" (Lk 23:34). During His public ministry, Jesus spoke of love for one's enemies: "[...] bless those who curse you, pray for those who mistreat you" (Lk 6:28). As He died on the cross for the salvation of the world, Jesus confirmed this teaching not through his words but through his very actions. As He hung on the cross, the Son of God asked the Father to forgive, and He carried out the work of justification.

Benedict XVI proved that, from the height of the Cross, it is possible to derive a message about the timeless wisdom that flows from It on the level of the antithesis of knowledge and ignorance. As he points out, although ignorance lessens human guilt, it is not a sufficient to justify man's guilt. Because of man's ignorance, Jesus begged God to forgive mankind. He argues that not even the extremely dramatic

\footnotetext{
1 J. Ratzinger, Wprowadzenie w chrześcijaństwo [Introduction to Christianity], Kraków 1996, 240.

2

Ibid., 226.
} 
circumstances of Jesus' death hindered Him because they served as a kind of gateway that opened humanity up to change and convert. ${ }^{3}$

The Pope points out that, as He hung on the cross, Jesus was mocked by three different groups of people: passersby (Mk 15:29), members of the Sanhedrin (Mt 27:42), and two revolutionaries (Mt 27:38; Mk 15:27). Of the two men condemned with Jesus, only one mocked him. The second recognized that Jesus Christ is God and perceived how, even though they had been accused of committing different crimes, they Fundamental received the same punishment. ${ }^{4}$ This man perceived the extraordinary attitude of his tortured and crucified companion and, after examining his conscience, cried out: "Jesus, remember me when you come into your Kingdom" (Lk 23:42). Ratzinger notes that Jesus' seemingly ordinary reply, "Today you will be with me in paradise" (Lk 23:43), is actually quite intriguing. Jesus is not referring to an abstract and distant realm in order to superficially console the dying thief. He uses very concrete timeline "today" and informs the man that He knows that immediately after he dies that he will enter the house of the Father. The Pope acknowledges: "With these words, Jesus, from the throne of the Cross welcomes every human being with infinite mercy." The condemned man, who is often referred to as the Good Thief, believed in Jesus on the cross and became a Christian example of hope and the certainty that Divine Mercy can touch man, even in the final moments of his life. A sinful life does eliminate neither a person's sense of prayer and nor his request for Divine Mercy.

In their Gospels, Saints Matthew and Mark include a description of the words that Jesus cried out at the ninth hour: "My God, my God, why have you forsaken me?" (Mt 27:46; Mk 15:34). The authors of the gospels write about this moment using a mixture of both Aramaic and Hebrew and then translate it into Greek. The Gospel writers did not omit this difficult passage from their accounts, and their decision to do so has led to many questions and reflections. People have wondered whether the Father could have abandoned the Son of God at all and what these words mean. The words that Jesus spoke clearly come from the Book of Psalms. Proclaiming the words from the Davidic Psalter, Jesus takes on Himself the suffering of the entire People of Israel and

3 Benedykt XVI, Jezus z Nazaretu, cz. II Od wjazdu do Jerozolimy do Zmartwychwstania, Kielce 2011, 221.

5

Ibid., 226.

Benedict XVI, “Angelus," November 21, 2010, http://www.vatican.va/content/ benedict-xvi/en/angelus/2010/documents/hf_ben-xvi_ang_20101121.html [01.01.2019] 
Fundamental Theology mankind, which is caused by his seeming abandonment by God. He addresses this cry to the Father Whom He loves. In this moment, when it seems as if God is silent and unresponsive, Jesus identified with helpless Israel and with the entire world. According to Pope Benedict XVI, by expressing the outcry of an oppressed world, Jesus takes on this attitude and transforms it not only through His own Resurrection, but also many who experience the Father's personal response in the resurrection of the body. ${ }^{6}$

John the Evangelist records that Jesus said the following from the cross to those closest to him: "When Jesus saw his mother and the disciple there whom he loved, he said to his mother, 'Woman, behold your son.' Then he said to the disciple, 'Behold, your mother.' And from that hour the disciple took her into his home" (Jn 19:26). This is Jesus final commendation-a spiritual adoption to ensure that Mary will be cared for after losing Her Son. John takes Jesus' place and is responsible for Mary from this moment on. This is a very human response of a dying Son. ${ }^{7}$ The expression "Woman," which Jesus used to refer to His Mother, cannot be explained without referring to the history of salvation. According to John's Gospel, Jesus uses this same expression to address His Mother at the Wedding at Cana (Jn 2:4). For John, this expression hearkens back to when God created Eve. In the creation account, Adam feels lonely even amid the richness of God's creation, so God created woman (Gen 2:22). Pope Benedict XVI points out that "Mary represents the new, the definitive woman, the companion of the Redeemer, our Mother: the name, which seemed so lacking in affection, actually expresses the grandeur of Mary's enduring mission." 8

Mary and the disciple whom Jesus loved were very real individuals, but they are also examples that Jesus gave for man to imitate. A woman-Mary-the Church is entrusted to the disciple who is united with the Lord in a communion of love. These words are realized anew in the lives of individuals and communities as a whole. They include not only the People of Israel but also the community of the Church and, with Her, all of humanity. ${ }^{9}$

J. Ratzinger, Wprowadzenie w chrześcijaństwo, 239.

Benedykt XVI, Jezus z Nazaretu, cz. II, 238.

8

Benedict XVI, "Homily," September 11, 2006 http://www.vatican.va/content/ benedict-xvi/en/homilies/2006/documents/hf_ben-xvi_hom_20060911_shrinealtotting.html [01.01.2019]. 
As Joseph Ratzinger indicates by referring to the words that John the Evangelist recorded: "And when I am lifted up from the earth, I will draw everyone to myself"" (Jn 12:32), the cross is the instrument by which Jesus draws humanity into his crucified arms and united it with God. The Son of God comes to help man who is lost-to help him reach the highest aim, which is union with his Creator. By freely laying His Body down on the cross, Jesus demonstrates that He lives not for himself; rather, His entire person is for others. Christ can be called the man of newness, the future, since He is completely open to others. The Pope shows that the first and basic right of Christians is determined by Christ sacrifice on the Cross-His being "for." ${ }^{10}$ The Christian's decision to accept Christ crucified should orient the Christian to cease to selfishly refer everything to himself and live for others. ${ }^{11}$

The Son of God's death on the cross is the only effective liturgy and atonement for man's sins. By shedding His blood on the Cross, Jesus made atonement to God for the sins of mankind, revealing a limitless love that has been poured out to the very end-a love that compels Oneself to agree to be torn, to be tormented, and to give everythingboth within and outside of oneself - to the point of the shedding the very blood from one's veins. ${ }^{12}$

Joseph Ratzinger denies that that Christ's crucifixion on the cross could have been a random event and points out the basic need for this event: "Jesus answered them: 'The hour has come for the Son of Man to be glorified. Amen, amen, I say to you, unless a grain of wheat falls to the ground and dies, it remains just a single grain of wheat but if it dies, it produces much fruit"' (Jn 12:24). The Pope also emphasizes that Jesus made a conscious decision to go up to Jerusalem, meaning the center of salvation history and the place where Jesus' destiny was to be fulfilled on the Cross and through His Resurrection. ${ }^{13}$

The Pope points out that, when Jesus speaks about the Cross before His hour had come, He encourages His followers to take up their crosses daily and imitate Him (Lk 9:23). In this way, man attains salvation and the joy of the resurrection by following the way of the cross with the Son of Man. Jesus died on the cross for man, so that man could

J. Ratzinger, Wprowadzenie w chrześcijaństwo, 233.

11 Ibid., 245.

12 Ibid., 277.

$13 \quad$ Benedykt XVI, Jezus z Nazaretu, cz. II, 242. 
Fundamental Theology

take up his own cross. By carrying his cross, man "dies" with Christ, but in so doing, becomes His companion in Christ's resurrection. ${ }^{14}$

In Chapter 10 of St. John's Gospel, Jesus says: "II will lay down my life for the sheep. I have other sheep that do not belong to this fold. These also I must lead, and they will hear my voice, and there will be one flock, one shepherd. This is why the Father loves me, because I lay down my life in order to take it up again" (15-17). This quote had an important influence on the burgeoning Christian communities and the first Christian synods. The rich theology of this passage was very useful when Church dogmas were developing rapidly at that time. The Church has tapped into this legacy to today. ${ }^{15}$ The following passage is found in the Book of Isaiah: "But it was the LORD's will to crush him with pain. By making his life as a reparation offering, he shall see his offspring, shall lengthen his days, and the LORD's will shall be accomplished through him" (Isa 53:10). In the gospel passage about the shepherd who lays down his life for the sheep, we this image from Isaiah as well as the fulfillment of the prophecy of the Messiah repeated.

Benedict XVI considers Jesus crucified the representative of all victims. He mentions that the 20th century was particularly rife with human cruelty and destruction. The Son of God's acceptance of the Cross, on which He was revealed to be the true "Lamb of God," should shake man and cause him to reflect on himself. This reflection should force man to consider with what kind of attitude he would respond when faced with Christ's Cross. Perhaps some individuals find that they are silent spectators of the Cross, while others contribute to the Redeemer's suffering. This consideration, however, should not be void of joy in the presence of God, Who identified with the innocent and suffering. ${ }^{16}$

Love comes through the Cross, since what is human was united once again with the Divine through Jesus' Cross. ${ }^{17}$ God's power is love and compassion. The true face of God is revealed in suffering. The Creator takes on Himself both His creation and the injustices of the world, so man, in his most difficult moments, can feel as close as possible to God. ${ }^{18}$ Only love properly guides suffering and gives it any

$14 \quad$ Benedict XVI, “General Audience,” March 9, 2011, http://www.vatican.va/content/benedict-xvi/en/audiences/2011/documents/hf_ben-xvi_aud_20110309.html [01.01.2019].

15 Benedykt XVI, Jezus z Nazaretu, cz. II, 218.

16 P. Seewald, J. Ratzinger, Bóg i świat [God and the World], Kraków 2005, 306.

$17 \quad$ J. Ratzinger, Wprowadzenie $w$ chrześcijaństwo, 238.

18 P. Seewald, J. Ratzinger, Bóg i świat, 311. 
kind of meaning. Through the love that led Him to the Cross, Jesus became the singular High Priest, Who offered Himself as a sacrifice in order to unite two clashing worlds. ${ }^{19}$ The love that Christ shows humanity on the Cross is an action, and this action becomes a Person. God comes to man in order to give Himself to man. From the power of His love, through offering the greatest sacrifice possible, God restores a broken covenant, justice, and order: "God was reconciling the world to Himself in Christ" (2 Cor 5:19). As Ratzinger highlights, this Fundamental is the phenomenon of the Cross. God does not wait for contrite man to come to Him and beg for forgiveness. The Almighty Himself takes the initiative to meet and reconcile with man, who has gone astray on different paths of life. God's action demonstrates how to become fully human, and it is through Christ's Cross. Without the Resurrection, the Christ's dying on the Cross would not be enough to initiate Christianity. Both events are closely related to each other. Everything that happened on the Cross would have been in vain if it were not for the Resurrection. ${ }^{20}$ The fulfillment of the tragedy of the Cross can be found in the Resurrection. ${ }^{21}$

\section{Death}

From a biological point of view, death is a natural and necessary process, while, from a theological point of view, death has spiritual potential because, in death, man passes from life to life. Temporality ceases, but this does not pose a threat to eternity.

In the person of Jesus, death reaches its highest dimension because it transcends its natural consequences. If one assumes that Christ remains in constant union with God the Father, then no one can claim that Jesus was annihilated in death. The union between the Son and Father is the source of immoveable existence, which, from a human point of view, is called "the brink of existence." In: a certain way, Jesus' death was necessary. Ratzinger points out that, on the level of temporal existence, the union of the Divine Son and God the Father does not cease. The people of Jesus' time often misunderstood Him. Yet, He fulfills His mission to redeem mankind. The final act of Christ's contemporaries' incomprehension takes place when they ultimately

\footnotetext{
19 J. Ratzinger, Wprowadzenie w chrześcijaństwo, 286. 
condemn and subject Him to His passion and death, thus rejecting Him and relegating Him to the realm of eternal silence through death. ${ }^{22}$

According to the Gospel, Jesus' death took place during prayer, at the ninth hour, meaning 3:00 PM. Luke the Evangelist states that Jesus' final words were those of Psalm 31:6: "Father, into your hands I commend my spirit" (Lk 23:46). In his Gospel, on the other hand, John records other words-namely, "It is finished" (Jn 19:30). Pope

Fundamental Theology

Benedict XVI emphasizes that the Greek equivalent of this text is the word "tetelestai." This expression refers to moment when Jesus washed the feet of His disciples during the Last Supper. As the Gospel writer recorded, before washing the disciples' feet, Jesus, having loved His own, He "loved them to the end" (Jn 13:1), meaning "teios." Ratzinger considers Jesus' death the ultimate fulfillment of Christ's declaration of love. Through his death, Christ reaches the final limit of the natural end of human existence and then transcends it, thereby creating a new prospect for existence. ${ }^{23}$

Ratzinger frequently emphasizes that Jesus' death has both liturgical and cosmic dimensions. The phenomena that accompanied Jesus the Nazarene's death (e.g., the temple veil torn in two, the eclipse, the earthquake, as well as the resurrection of the dead) are proof of this.

By approaching Jesus on the Cross, the soldiers-by virtue of their profession and experience-confirmed that the Son of Man had already dead. This is why they did not bother to break His legs. In order to quell any doubts, one soldier pierced Jesus' heart through the right side with a lance: "but one soldier thrust his lance into his side, and immediately blood and water flowed out" (Jn 10:34). According to Ratzinger, Jesus reveals Himself as the perfect sacrifice-the true Paschal Lamb. This is an expression that harkens back to the beginning of Jesus' earthly ministry, when, upon seeing Jesus, John the Baptist proclaims: "Behold, the Lamb of God, who takes away the sin of the world" (Jn 1:29). When they heard this expression, the Apostles did not understand what it meant. It was not until after Jesus died that they understood the deep meaning of this expression. Jesus' disciples realize that these words were a prophecy. As the "Lamb," Jesus carried the sins of the entire world upon Himself to the Cross and took

\footnotetext{
22 J. Ratzinger, Bóg Jezusa Chrystusa. Medytacje o Bogu Trójjedynym, Kraków 1995, 84 . 
them away. ${ }^{24}$ According to Ratzinger, the Son's role as the Lamb of God changes humanity. ${ }^{25}$

Jesus is an instrument in God the Father's hands, Who justifies, forgives, and, consequently, reconciles man through His death. Like St. Paul, Pope Benedict XVI hopes that every person who dies like Christ will also experience the resurrection. In this sense, death is the basis of the Christian argument for hope that the resurrection is universal: "for, just as in Adam all die, so too in Christ shall all shall be brought to life" (1 Cor 15:22).

The reference to Jesus' death can also be found in Psalm 34: "Many are the troubles of the righteous, but the LORD delivers him from all. He watches over all his bones; not one of them shall be broken" (20-21). In specific passages of the Old Testament regarding the execution of the Messiah, Benedict XVI sees the source of faith in the proclamation of the redemptive work of Jesus, who must suffer by taking the sins of the world upon Himself. ${ }^{26}$

In his Gospel, St. John the Evangelist writes that: "but one soldier thrust his lance into [Jesus'] side, and immediately blood and water flowed out" (Jn 19:34). Tradition maintains that this event is even the source of the sacraments. Through His death, Christ became this source. ${ }^{27}$ The Pope strives to restore the rightful place of Christ's corporeality and, thereby, the entire person of the Son of God and His work through the allegory of blood and water. ${ }^{28}$ The Holy Father indicates in Christ's open side the parallel to Eve, who was formed from the rib of Adam while he was sleeping. In agreement with the Fathers of the Church, Ratzinger emphasizes that the Church was created based on the model of Eve: The Church was formed from the open wound of Her Spouse, Jesus, Who brings new life from death. ${ }^{29}$

Biblical passages that testify to the Jesus' crucifixion and death can be found in St. Paul's First Letter to the Corinthians (1 Cor 15:3-8). This letter serves as St. Paul's creed, in which he begins by emphasizing

$24 \quad$ Ibid., 240.

25 P. Seewald, J. Ratzinger, Bóg i świat, 106.

26 J. Ratzinger, Jezus z Nazaretu, cz. II, 240.

27 Por. Catechism of the Catholic Church, 1225.

28 The First Letter of St. John refers to this issue: "This is the one who came through water and blood, Jesus Christ, not by water alone, but by water and blood. The Spirit is the one that testifies, and the Spirit is truth. So there are three that testify, the Spirit, the water, and the blood, and the three are of one accord" (5:6-8). 
Fundamental Theology

Jesus' death. There are two important details to add about Christ's death: "in accordance with the scriptures" and "for our sins." The words "according to the scriptures" situate Christ's death within the context of Old Testament covenant between Yahweh and His people. In this way, the death of the Messiah is connected to the history of salvation, and, therefore, is not coincidental. In other words, history makes Christ's death logical and gives it a broader meaning. Jesus is the fulfillment of the messianic ideas contained in Old Testament writings. ${ }^{30}$

The second phrase "for our sins" provides insight that makes it possible to interpret Jesus' death correctly. This expression relates to the words of the Prophet Isaiah: "For he was cut off from the land of the living, struck for the sins of his people [...]. Therefore I will give him his portion among the many, and he shall divide the spoils with the mighty, because he surrendered himself to death, was counted among the transgressors, bore the sins of many, and interceded for the transgressors" (Is 53:8, 12). The first Christian communities knew this passage very well, and these words are clearly echoed in St. Paul's writings. ${ }^{31}$ Ratzinger emphasizes that Jesus' death was different than the death of any other person. Christ's death was not the result of sin and the pride of making oneself equal to God, but rather His act of love so that man would not be left to himself and deprived of eternity. Christ's death is the death of the Servant of God-a death of redemption, which reconciles God and His people. Thus, Christ's death overcomes death. When analyzing the aforementioned issues carefully, Ratzinger perceives that the expression "he has died" indicates that the prospect of the Resurrection begins on the Cross. ${ }^{32}$

Through Christ's death, His descent into hell was accomplished. This fact is recorded in the Creed. In terms of exegesis, this article touches on new topics that are significant with regard to interpretation of the Resurrection. The word "hell" in the Creed is an incorrect translation of the word "sheol" ("hades" in Greek), which means the place to which man goes after he dies. Hades is the underworld and implies a realm of shadows where the human soul lives in a state closer to non-being than being. From the beginning, Jesus' descent into sheol was interpreted as the true knowledge of death. At this point, as the Bishop of Rome points out, it is difficult to analyze Jesus' descent into hell in depth because man cannot return from death to describe its mystery.

\footnotetext{
30 J. Ratzinger, Bóg Jezusa Chrystusa, 95.

31 Paweł VI, J. Ratzinger, R. Cantalamessa, A. Pronzato, et al., Przesłanie Zmartwychwstania, Kraków 2002, 21. 
If a loneliness into which neither a word, presence, nor love can break exists, then it certainly is an image of hell. Because there is an absence of love in loneliness, then this very loneliness is a threat to man's existence. All anxiety arises from the ultimate fear of loneliness, which reaches its apex in death. The Old Testament contains only one word for hell and death: sheol. In the New Testament, the situation changes through the intercession of the person of Christ, who passed over the threshold of the ultimate and deepest human loneliness. He entered into the abyss of human isolation, emptiness, nothingness, and darkness, where all hope was gone and for which, until He had come, there was no effective antidote. He descended to where no voice could reach and pierced the eternal silence. The realm of hell was defeated once and for all. Death, meaning sheol or hell, which was the final destination for all of humanity, ceased to be such. Life arises in Christ's death because love is found in it. Hell, therefore, is only for those who freely turn away from God's love and choose isolation. The final book of the New Testament proclaims that "Then death and hades were thrown into a pool of fire" (Rev 20:14). The second term-hades-indicates that this state is secondary. The state of death ceases to be a reality immersed in loneliness. The Evangelist Matthew describes that "tombs were open, and the bodies of many saints who had fallen asleep were raised. And coming forth from their tombs after his resurrection, they entered the holy city and appeared to many" (Mt 27:52-53). In other and opposite words: the Evangelist Luke tries to describe life and death, or more precisely what happened when Christ descended into hell. Through His death, Jesus descended to the kingdom of the dead, but having return to the Kingdom of Life, he is the Ruler of the Living - the only One who could lead those who believe in Him from the realm of darkness into light-to transform sorrow into joy, error into truth, and death into life. ${ }^{33}$ The effect of Christ's victory over death is both personal and applies to the just who live before the coming of the Redeemer.

A Christian must be aware that death-man's enemy, which seeks to deprive him of life at all cost-has been overcome wherever man opposes it by entrusting himself to God's love. When one loses his life, he gains it. Christ conquered death, but death is also overcome wherever man dies with and in Christ. ${ }^{34}$

33 Paweł VI, J. Ratzinger, R. Cantalamessa, A. Pronzato et al., Przestanie Zmartwychwstania, 53 .

34 J. Ratzinger, Śmierć $i$ życie wieczne [Eschatology: Death and Eternal Life], Warszawa 1986, 115. 


\section{The Resurrection}

The Resurrection of the Son of God was a turning point in human history. The Resurrected Christ was the Only Witness of this event. What the Son of God did after His Resurrection as well as the circumstances surrounding His appearances to others on earth is known only to those of his time. These Christ's appearances to people after His

Fundamental Theology
Resurrection are called Christophanies.

The first descriptions of Christophanies date back to the first day after the Sabbath when the women found the tomb empty at dawn (Mt 28:2). When analyzing the accounts of those who encountered the Resurrected Christ, Ratzinger notes that it was not easy for them to describe their experiences. The witnesses were confronted with an entirely new reality that neither they nor humanity in general had ever experienced before. As later accounts convey, these encounters with the Resurrected Christ differed. These Christophanies not only shocked and terrified but also created a sense of euphoria in those who experienced them. Regardless of how the witnesses reacted, these Christophanies always resulted in a profession of faith in the Resurrected Christ. Although the accounts and reactions of those who "saw" the Risen One differ, they frequently speak of a mysterious image that is rationally difficult to describe, but is very real and experiential.

New Testament accounts confirm that the Resurrection was something completely new and unique. Christ's entrance into new life, where the laws of death no longer apply, ushered in a new dimension of existence wherein man perceives his purpose and destiny in a new way. The Resurrection is not a singular event that occurred only in the past and pertained only to the person of Jesus. Rather, new ways of being human were brought about in Jesus' Resurrection, the consequences of which affect all people and open before them the doors to a completely new future. For St. Paul, Jesus' Resurrection and the resurrection of man are inseparable: "For if the dead are not raised, neither has Christ been raised [...] as the firstfruits of those who have fallen asleep" (1 Cor 15: 16, 20). Paul notes that the resurrection takes place only in Christ for those who believe in Him. To become a believer is a process just like a person's attitude toward the Cross. The Resurrection, like the Cross itself, was no less real to disciples. After the disciples initially disbelieved and were amazed, they became certain that the very One Who was alive, speaking to them, and permitting them to touch Him is real. This was a great paradox; Christ was no longer of the world, but $\mathrm{He}$ was alive and exists. Christ was not just a resuscitated corpse that would die again. The Pope writes that the 
Resurrection was a singular event-the only of its kind, that transcended all predictions and foreseeable possibilities. This, however, did not prevent the Resurrection from being a real and decisive event. ${ }^{35}$

Benedict XVI points out that two different narratives are predominant among the testimonies about the Risen Christ. The first kind of narrative is the profession of faith that completely overlooks the testimonies of the women and focuses only on Christ's appearances to men. The second type is narrative tradition in which women play a leading role. ${ }^{36}$

The tradition of the accounts that contain a profession of faith contain short but important phrases that have become expressions of Christian identity over time. Thanks to these expressions, Christians were able to identify each other and express their entrustment to God. The two disciples who found themselves on the way to Emmaus is perfect example. Their journey ended in a dramatic way because they did not arrive at their destination. Through the circumstances of their encounter with Christ, they returned instead to Jerusalem (and not Ephesus) in order to meet with Jesus' disciples who were gathered there and greeted them with the words: "The Lord has been truly raised" (Lk 24:34). This greeting quickly became a proclamation and profession of the essence of the Christian faith. ${ }^{37}$ This is likely one of the oldest known passages about the Resurrection. Over time, it became a means by which Christians identified each other. The greeting also laid the foundation for the tradition of using one's confession of faith as a way to present the Resurrection..$^{38}$

The reaction of Mary Magdalene who, upon finding the tomb empty, claims that someone must have taken Jesus' Body is an example of St. John the Evangelist's narrative tradition: "On the first day of the week, Mary of Magdala came to the tomb early in the morning, while it was still dark, and saw the stone removed from the tomb. So she ran and went to Simon Peter and the other disciple whom Jesus loved, and she told them, 'They have taken the Lord from the tomb, and we don't know where they put him"' (Jn 20:1-2). Ratzinger confirms that the Gospel accounts of the Resurrection differ from each other. For example, St. Matthew describes Jesus' appearances to the women at the empty tomb and in Galilee to the eleven Apostles. St. John writes

\footnotetext{
35 J. Ratzinger, Jezus z Nazaretu, cz. II, 263.

36 Ibid., 280.

37 Ibid., 264.

38 Paweł VI, J. Ratzinger, R. Cantalamessa, A. Pronzato, et al., Przestanie Zmartwychwstania, 18.
}

Fundamental

Theology 
Fundamental Theology

about Jesus' appearances in Galilee and Jerusalem. None of the Evangelists, however, describe the Resurrection itself, which was a mysterious event known only to the Father and the Son. The nature of this event remains hidden from man and transcends human experience. ${ }^{39}$

In the Gospels, Christ appears in human form after His Resurrection and does different things in order to show that He has a body. This resurrected body, however, is different than the one that Christ had before His death. For example, the Redeemer is able to pass through closed doors and to disappear suddenly. In His resurrected body, Christ is not subject to the laws of space and time to which an ordinary person is subject. Christ's resurrected body maintains certain bodily features by which His disciples recognize Him as their Teacher. However, the accounts report that Christ's existence is completely different after the Resurrection, and those who saw Him had never encountered or experienced this before. As a result, it was difficult for them to find the words to describe what they witnessed and experienced. ${ }^{40}$

The Gospels and the books of the New Testament describe the resurrected Christ in various ways. For example, the three Christophanies described in the Acts of the Apostles and the conversion of St. Paul contain two similar elements: a light and a voice. In the first account, those accompanying St. Paul hear a voice, but they do not see anyone: "The men who were traveling with him stood speechless, for they heard the voice but could see no one" (Acts 9:7). In the second account, however, the opposite occurs, and they see a light, but do not hear a voice: "My companions saw the light but did not hear the voice of the one who spoke to me" (Acts 22:9). The third account does not contain the aforementioned details; rather, it only conveys that everyone fell to the ground: "We all fell to the ground and I heard a voice s[peak] ing to me in Hebrew" (Acts 26:14). Paul and those who accompanied him did not experience the same thing. Clearly, only St. Paul received the vision directly. Those accompanying him on the journey were only witnesses of the extraordinary event, which was proven by the fact that they all fell to the ground. The Risen One, Whose being is light, communicated with Paul in a human voice and in Paul's own language.

St. Paul's experience differs from the experiences of other people who witnessed the Resurrected Christ. When the Lord appeared to other people immediately after His crucifixion, Paul was busy persecuting the growing Church. Paul highlighted his mission: "But by the grace of God I am what I am, and his grace to me as not been ineffective.

\footnotetext{
$39 \quad$ J. Ratzinger, Jezus z Nazaretu, cz. II, 279.

$40 \quad$ Ibid., 283.
} 
Indeed, I have toiled harder than all of them; not I, however, but the grace of God [that is] with me" (1 Cor 15:10). Paul, however, strives to emphasize before all else that his preaching of the Gospel corresponds completely with the other Apostles' preaching. The faith of the communities that St. Paul established is also based on the accounts of those who witnessed the Resurrection:" "Therefore, whether it be I or they, so we preach and so you believed" (1 Cor 15:11).

The experiences that people had in their encounters with Christ Theology after His Resurrection are different than interior or mystical occurrences. These experiences were true encounters with the Living Christ, Who manifested Himself in a new way in His corporeal resurrected body. A very interesting phenomenon that Ratzinger points out is the way in which Jesus partook of food after His Resurrection. Such accounts are mentioned in the Gospels three times and in the Acts of the Apostles once. The first account mentions how Jesus ate with his disciples who were on their way to Emmaus. This story ends with Jesus sitting with these disciples at table, taking bread, saying the blessing, and breaking and sharing the bread. The disciples recognized Jesus through these actions, but He vanished from their sight (Lk 24:31).

The second instance occurred when the disciples were convinced that they were seeing a ghost, and Christ urges them to touch the wounds in His hands and feet and then asks them for something to eat: "While they were still incredulous for joy and were amazed, he asked them, 'Have you anything here to eat?' They gave him a piece of baked fish; he took it and ate it in front of them" (Lk 24:41-43). The structure of the aforementioned accounts of Christ eating are similar to the accounts found in the Gospel of John where, after an unsuccessful night of fishing, the Apostles see Jesus standing on the shore from where He called to the Apostles and asks them whether they have caught any fish. After they respond in the negative, Jesus tells them to cast out their net again. Soon after, they return to the shore with a net full of fish and see that the Resurrected One had prepared some fish and bread. Jesus invites them to eat breakfast, and by this they recognized that it was the Lord (Jn 21:1-14).

Christophanies confirm the fact that Jesus did not return to the same biological state before His Resurrection and the die again, thereby ending the cycle of his life. The Risen One is not a ghost, spirit, vision, or someone who returned from the underworld-from the land of the dead in order to appear to the living. The essence of Christ's

41 Paweł VI, J. Ratzinger, R. Cantalamessa, A. Pronzato, et al., Przestanie Zmartwychwstania, 32 . 
Fundamental Theology

Resurrection is the fact that it transcends the limits of history and creates a new dimension with which eschatology deals.

Christ's Resurrection was an assurance of the resurrection that will occur at the end of time. Benedict XVI points out that Christians should unceasingly grow in their intimacy with Christ, Who died and rose from the dead for each person. Christ's Passion is the passion of every person who believes, since Christ's Resurrection is the assurance of the resurrection of man. As the Pope states, the good news never ceases because Jesus is always alive. Ratzinger recalls St. Augustine, who confirms that the Resurrection is the foundation of the Christian faith. Jesus' Resurrection not only authenticates His work, but also opens up new spaces in which the resurrection of man is possible. ${ }^{42}$

Some of the issues that Ratzinger considers in his reflections on the resurrection of the dead are the immortality of the soul and the resurrection of the body. It is difficult to speak about either the immortality of the soul or the resurrection of the body without referring to both at the same time. For, neither of these realities can be comprehended by reason or understood by science. Even if an explanation of these realities included a kind of transformed Cosmos or new corporeality, the question still remains: What happens after man, who "waits" until the "end of time," dies? Luther spoke of a so-called "soul sleep," ${ }_{43}$ but this not a sufficient response for those who claim that the soul does not exist.

Benedict the XVI indicates that, according to the Bible, man's immortality should always be understood as a resurrection that occurs through the Creator. ${ }^{44}$ As Benedict points out, because of the Thomas Aquinas, the field of theology came to the unheard of conclusion that the "spirit in man constitutes such a union with the body that it can be called the form, and the form of the human body is the spirit that makes man a person." From this comes the assertion that the separation of body and soul is against human nature and undermines man's likeness to God. In this way, that which philosophically seemed to be at odds is, in fact, connected. The soul belongs to the body as its "form," but it is still spirit, thereby opening man to immortality. ${ }^{45}$ As Ratzinger points out, the immortality of the soul does not come from the soul

42 Benedict XVI, “Homily,” March 16,2008, http://www.vatican.va/content/benedictxvi/en/homilies/2008/documents/hf_ben-xvi_hom_20080316_palm-sunday.html [ 01.01.2019].

43 Por. J. Finkenzeller, Eschatologia, Kraków 1995, 110.

44 J. Ratzinger, Wprowadzenie w chrześcijaństwo, 294.

$45 \quad$ J. Ratzinger, Śmierć i życie wieczne, 168. 
itself. It soul not an intrinsic "substance" as some have claimed. Life after death is possible for man only because the will and action of the Lord God make it so. This pertains to both believers and non-believers. In his actual death, man loses himself, and God, through the resurrection, restores man to himself so that he can stand before the judgment seat of the Creator and live. ${ }^{46}$ According to Ratzginer, God's dialogue with man means life-it means that Christ as God's Word addressed to every person becomes "the resurrection and the life" itself (Jn 11:25). This means that faith in the Son of God is to begin knowing and loving man through God, who is immortality itself. As a result, the one who believes in the Son will "have eternal life" (Jn 3:15).

\section{Conclusion}

Christ's Cross, death, and Resurrection are the three mysteries that assure mankind that life has another, eternal dimension in God. This dimension was made possible because of the mystery of the Son of God's Resurrection. Christ's Passion and Death on the Cross led the Son of God and man to the prospect of the Resurrection. The love of God became infinitely valuable on the Cross, the power of which conquered sin and death and became the foundation of the Resurrection. ${ }^{47}$ Christ took up the Cross out of love and paved the way to eternal life for every person. Ratzinger points out that immortality is a dialogue of love between man and God. This dialogue takes place in an atmosphere of sacrificial love. God immortal became incarnate in Jesus Christ, from Whom man receives the bread of immortalitythe Sacrament of the Eucharist. Because of this Sacrament man has life in God. Man does not have the power to bring about eternal life. ${ }^{48}$ God the Creator and Redeemer, who cares for man, is the source of believers' hope in life after death. Man is not alone in his relationship with God, and eternal life is not only a relationship between man and God. Man's dialogue with God takes place through people, within the community of the children of God, and comes to fruition in the Church through communion with the Son of God. This relationship makes it possible for man to call God his Father insofar as man himself, in union with the Son of God, also becomes God's child. Dialogue with God becomes truly human because God leads man as a Man Himself, and this interpersonal dialogue reaches into love in eternity by the

\footnotetext{
$46 \quad$ Ibid., 169.

$47 \quad J$. Ratzinger, Wprowadzenie w chrześcijaństwo, 299.

$48 \quad$ J. Ratzinger, Śmierć i życie wieczne, 176.
} 
Fundamental Theology

fact it becomes grafted onto the Trinitarian relationship of the Divine Persons. Eternity opens up before man in the communion of saints, which emphasizes that man is in no way isolated in eternal life. On the contrary-eternal life draws man out of isolation to true unity with his brothers, sisters, and all of divine creation. Christ's Resurrection is the basis for the resurrection of man. Christ's Resurrection was made possible due to the Cross, which led to His heavenly glory. When man lives with Christ, he enters into a relationship of love that leads to the cross, which transforms time and is a precursor to eternity.

\section{Bibliography:}

1. Benedict XVI. "Angelus.” November 21, 2010. http://www.vatican.va/content/benedict-xvi/en/angelus/2010/documents/hf_ben-xvi_ang_20101121. html [01.01.2019].

2. Benedict XVI. "General Audience." November 5, 2008. http://www. vatican.va/content/benedict-xvi/en/audiences/2008/documents/hf_benxvi_aud_20081105.html [01.01.2019].

3. Benedict XVI. "General Audience." March 9, 2011. http://www.vatican. va/content/benedict-xvi/en/audiences/2011/documents/hf_ben-xvi_ aud 20110309.html [01.01.2019].

4. Benedict XVI. "Homily." September 11, 2006. http://www.vatican.va/content/benedict-xvi/en/homilies/2006/documents/hf_ben-xvi_hom_20060911_ shrine-altotting.html [01.01.2019].

5. Benedict XVI. "Homily." March 16, 2008. http://www.vatican.va/content/ benedict-xvi/en/homilies/2008/documents/hf_ben-xvi_hom_20080316 palm-sunday.html [01.01.2019].

6. Benedykt XVI. Jezus z Nazaretu, cz. II Od wjazdu do Jerozolimy do Zmartwychwstania [Jesus of Nazareth, Part II: Holy Week: From the Entrance into Jerusalem to the Resurrection]. Kielce 2011.

7. Catechism of the Catholic Church. Vatican City 1994.

8. Finkenzeller, J. Eschatologia. Kraków 1995.

9. Paweł VI, Ratzinger, J., Cantalamessa, R., Pronzato, A., et al. Przestanie Zmartwychwstania. Kraków 2002.

10. Ratzinger, J. Bóg Jezusa Chrystusa. Medytacje o Bogu Trójjedynym. Kraków 1995.

11. Ratzinger, J. Śmierć i życie wieczne [Eschatology: Death and Eternal Life]. Warszawa 1986.

12. Ratzinger, J. Wprowadzenie w chrześcijaństwo [Introduction to Christianity]. Kraków 1996.

13. Scheffczyk, L. Zmartwychwstanie. Warszawa 1984.

14. Seewald, P., Ratzinger, J. Bóg i świat [God and the World], Kraków 2005. 